\title{
JOHN F. KENNEDY AND THE DESIRE TO LAND AN AMERICAN ON THE MOON
}

\section{LEWIS CLEGG}

Within the first few months of John F. Kennedy's tenure as president in 1961, he announced an ambitious goal for his administration: that by the end of the decade the United States would land an American on the moon. This bold agenda would lead to one of America's greatest achievements, when Neil Armstrong stepped foot on the moon in 1969. This event also reflected many elements of the Cold War, which prompts the question of how did the Cold War influence Kennedy's launch of the Apollo program in 1961? Also, how did Kennedy connect this ambition to fighting the Cold War? This paper argues that Kennedy adopted the Apollo program due to the pressure evoked on him by the success of the Soviet space program during the Eisenhower administration and the political embarrassments of his early presidency, being the Yuri Gagarin spaceflight and failed Bay of Pigs invasion. Kennedy's space efforts reflected a response to the Cold War conflicts, both inherited from the Eisenhower administration and new struggles emerging during his own presidency. Space became a means to highlight American superiority, both ideologically and militarily. Kennedy's speeches and actions reflected this, as he pushed his lunar goal as a national effort and a reflection of American democracy and way of life.

Firstly, the space race began under President Eisenhower's administration and with the success of the Soviet space program. During and after the Second World War, both superpowers had developed several advanced weapons, science, and technological programs. 
${ }^{1}$ In the mid-1950s both nations planned on launching artificial satellites into orbit around Earth. These programs emerged from the missile arms race. Both nations were rapidly developing advanced weapons technology and the capability of launching objects into space via newly developed rockets. Space emerged as a way to advance the arms race, as each side would have the ability to take pictures from space for defense purposes. Making progress in this frontier would also provide an ideological and propaganda victory in the early Cold War. ${ }^{2}$ On October 4, 1957, the Soviets won the satellite race with Sputnik, the first successful satellite to be put into Earth's orbit. For the scientists involved in both programs, Sputnik was seen as a major success in the field of science and technology, and the Americans congratulated their counterparts. ${ }^{3}$ Although the U.S. media spun Sputnik into a disaster for the U.S., Eisenhower and his administration did not share the same level of concern. Despite this lack of concern, Eisenhower responded to the propaganda coup by Soviet and U.S. media, pressure from his political rivals, and worries of the U.S. public by pushing for increased research and development of space projects in the name of national security and U.S. prestige on the global stage. ${ }^{4}$ This obsessive chase to imitate and eventually surpass the Soviet Union was not because Sputnik was important, but rather "it seemed so" psychologically to the American people, who felt the best way to beat the Soviets was to become more like them. ${ }^{5}$

Moreover, President Eisenhower's response to political pressure of Sputnik came during his State of the Union address in 1958. Many of Eisenhower's critics, most notably Democratic

\footnotetext{
${ }^{1}$ Gerard J. DeGroot, Dark Side of the Moon: The Magnificent Madness of the American Lunar Quest (New York: New York University Press, 2006), 39-40.

${ }^{2}$ Walter A. McDougall, The Heavens and the Earth: A Political History of the Space Race (Baltimore.: Johns Hopkins University Press, 1997), 55-62.

${ }^{3}$ DeGroot, 57-59.

${ }^{4}$ DeGroot, 57.

${ }^{5}$ DeGroot, 59.
} 
senators, spun Sputnik into the loss of American values and way of life that Eisenhower championed so greatly. ${ }^{6}$ The U.S. media, public, and many Democrats in the house saw this as a blow to U.S. science and technology, too, as Senate Majority Leader Lyndon B. Johnson claimed "in the eyes of the world, first in space means first, period; second in space is second in everything." ${ }^{, 7}$ Eisenhower needed a major response to this political and public pressure as to not undermine his reputation and accomplishments he garnered during the first term of his presidency. During his 1958 State of the Union address, Eisenhower called for rapid acceleration of research, funding, and development of science and technological programs and that a nonmilitary space civilian agency be established. There were also major investments made into teaching and scholarships related to matters of "national security" and a doubling of research funds to the National Science Foundation. ${ }^{8}$ The space agency bill was later approved and passed in Congress, and the National Aeronautics and Space Administration (NASA) was established in 1958. Eisenhower took on these initiatives while not being wholly comfortable. However, in response to the national outcry of Sputnik, Eisenhower had to put his personal beliefs aside. ${ }^{9}$ Eisenhower confessed his failure to anticipate the psychological impact of Sputnik and hoped these measures would meet the demands of the Cold War put on the United States. Ike may not have been confident in these policies, but it was part of the new reality of the space race, and he would soon be replaced as America's leader in the matter.

Before President John F. Kennedy was inaugurated, he was very quiet and limited in his beliefs regarding the space race. Several personal letters and private meetings with important

\footnotetext{
${ }^{6}$ McDougall, The Heavens and the Earth, 132-133.

${ }^{7}$ Walter A. McDougall, 2010, “1961: Shooting the Moon: Practical Rather than Idealistic Reasons Pushed President Kennedy to Challenge America to Land a Man on the Moon within the Decade," (Modern Era 1946-2010) (John. F. Kennedy), American Heritage, Para, 4.

${ }^{8}$ McDougall, The Heavens and the Earth, 158-159.

${ }^{9}$ McDougall, The Heavens and the Earth, 172-176.
} 
scientists indicate that the Kennedy brothers were not too bothered by the Soviet success of Sputnik. Rather, John F. Kennedy, as a U.S. Senator in 1957, was more concerned with foreign policy and defense of the United States. Kennedy's primary concern was the growing "missile gap" between the Americans and the Soviets. Kennedy even expressed these concerns on the Senate floor on August 14, 1958, claiming that the Soviet Union's superiority in nuclear missiles would allow them to shift the balance of global power against the U.S. When Kennedy did speak about space issues, it was linked with missiles, with the term "missile-space problem" being coined..$^{10}$ Kennedy did vote in favour of the establishment of NASA, however, and within two years was beginning to give even greater consideration to space issues. In a private letter exchange with William Everdell in 1960, Kennedy regarded America's "inferior position in space exploration" as a national frailty, but not as one of the prime national issues. As a senator, Kennedy viewed space as a national embarrassment and issue needing to be addressed, but it was not as important to him as foreign policy or the arms race, which Kennedy advocated the space race stemmed off of. Kennedy's views began to change as he ran for president, as many close advisors and influential Democrats emphasized the greater importance of the space race in fighting the Cold War. According to Kennedy's closest policy adviser, Theodore C. Sorensen, JFK thought of space primarily in symbolic terms. Sorensen claimed Kennedy complained endlessly about the Eisenhower administration's lack of effort, initiative, and imagination in the space race. Kennedy felt that the success of the Soviets in space not only embarrassed the Eisenhower administration, but also the office of the presidency. ${ }^{11}$

Moreover, during Kennedy’s Democratic Party nomination acceptance speech on July 15, 1960, he stated that America was entering "a New Frontier", and "Beyond that frontier are

\footnotetext{
${ }^{10}$ John M. Logsdon, John F. Kennedy and the Race to the Moon (NewYork: Palgrave Macmillan, 2010), 6-7.

${ }^{11}$ Logsdon, John F. Kennedy and the Race to the Moon, 7-8.
} 
uncharted areas of science and space."12 Although the "New Frontier" Kennedy mentions in his nomination speech refers to many different aspects of the nation, he lists space first. The platform that Kennedy also ran on stated that:

The Republican Administration has remained incredibly blind to the prospects of space exploration. It has failed to pursue space programs with a sense of urgency at all close to their importance to the future of the world.

The New Democratic Administration will press forward with our national space program in full realization of the importance of space accomplishments to our national security and our international prestige. We shall reorganize the program to achieve both efficiency and speedy execution. We shall bring top scientists into positions of responsibility. We shall undertake long-term basic research in space science and propulsion. ${ }^{13}$

This was very much an election strategy used by Kennedy, as after he was elected president in November 1960, there was little discussion of the issue of space before his inauguration. There was no contact with NASA, no mention of who would be the new NASA administrator, and uncertainty on the space front heading into the Kennedy administration. ${ }^{14}$ Kennedy was able to link the space race to other theatres of the Cold War he felt were more important, such as the arms race, foreign policy, and presenting a positive image of America abroad during the election. What then would be the factors that led Kennedy to launch the creation of the Apollo program in his Congressional address half a year later?

The political and public pressure of the space race and Cold War carrying over from the Eisenhower administration was the first factor in Kennedy's decision to launch the Apollo program. Kennedy had large shoes to fill, as Eisenhower was a World War II hero and a popular president for the most part. Many were sceptical of Kennedy's youth and his inexperienced cabinet, which was on average ten years younger than that of Eisenhower's. Kennedy appointed

\footnotetext{
12 John F. Kennedy, "The New Frontier," Democratic National Convention Nomination Acceptance Address delivered at Memorial Coliseum, Los Angeles (15 July 1960), para. 6.

${ }^{13}$ Democratic Party Platform of 1960, July 11, 1960, Retrieved from Logsdon, 8.

${ }^{14}$ Logsdon, John F. Kennedy and the Race to the Moon, 13.
} 
many highly respected intellectuals who would help him address many troubling domestic and foreign policy problems. The most notable of these was his brother Robert Kennedy, who became the attorney general. ${ }^{15}$ These were all themes featured in his inaugural address, too. The issue was that fellow Democrats saw the space race as intrinsically linked to other initiatives Kennedy believed in. Sputnik was still in the media and public's mind, and Kennedy was not addressing the issue as he promised in his campaign.

Another important event that occurred at the end of the Eisenhower presidency was the U-2 spy plane incident, which made Cold War relations even tenser. On May 1, 1960, the Soviets shot down an American U-2 reconnaissance aircraft engaging in espionage surveillance of Soviet military sites. American pilot Francis Gary Powers was subsequently captured by the Soviets. In the five years prior to this event, President Eisenhower and Soviet leader Nikita Khrushchev had taken some cautious and politically risky steps to rapprochement, although the efforts and progress were painfully slow. Now all progress had been lost, as this international crisis marked a period of increased tension and recrimination between the two superpowers. ${ }^{16}$ Eisenhower offered a "plausible denial” at first, as Powers was assumed dead. To Eisenhower's dismay, the Soviets revealed Powers publicly and charged him with conducting espionage against the state. Eisenhower refused to apologize to the Soviet Union, and this event marked a major embarrassment for his administration. ${ }^{17}$ This one event created a strained relationship with the Soviet Union for Kennedy when he was elected president half a year later. Although the U-2 spy plane incident did not affect the space race directly, it created a tense Cold War atmosphere,

\footnotetext{
15 Thomas C. Reeves, A Question of Character: A Life of John F. Kennedy (New York: Free Press, 1997), $225-228$. ${ }^{16}$ E. Bruce Geelhoed, "Dwight D. Eisenhower, the Spy Plane, and the Summit: A Quarter-Century Retrospective," Presidential Studies Quarterly 17, no. 1 (March 1987): 95-96.

${ }^{17}$ R. Cargill Hall, "Denied Territory: Eisenhower's Policy of Peacetime Aerial Overflight," Air Power History 56, no. 4 (Winter 2009): 9.
} 
which would contribute greatly to the political and media pressure on Kennedy during Cold War conflicts that emerged during his presidency.

However, once Kennedy had selected his cabinet, his administration was ready to tackle the issues regarding the space race and Cold War at large. Many of these issues included the relationship between the military and civilian space efforts, which became a major issue with the introduction of NASA. Eisenhower had advised that NASA be created as a civilian agency responsible for non-military space projects. However, since weapons and space technology were so tightly interlinked before the establishment of NASA, the military controlled all space activities. In October 1959, Eisenhower approved the transferal of the military's remaining space-related programs to NASA. This did not bode well with two branches of the military, as following Sputnik, both the U.S. Army and Air Force put forward ambitious space plans. ${ }^{18}$ Once NASA was approved by Congress, many of these plans were scrapped or altered by the new civilian agency, and the military's role in the space effort declined. The Army was much more content with taking a minor role in the new space efforts than the Air Force, but Kennedy was quick to change this. ${ }^{19}$ These issues highlight the connections of space to the rest of the Cold War. Eisenhower's reluctance to address this issue head on became problematic, as the former military man had strong relations with the military and their programs. The unresolved issue was inherited by Kennedy, a president who needed good relations with the military to address his worry of the missile gap between the two powers and soften political pressure from party members who advocated greater spending and resources to the space race. Once members of Kennedy's cabinet advised him on many of the issues facing the space program, he quickly began to act. The most notable individual was Trevor Gardiner, a former Air Force assistant

\footnotetext{
${ }^{18}$ McDougall, The Heavens and the Earth, 164-172.

${ }^{19}$ Logsdon, John F. Kennedy and the Race to the Moon, 18-22.
} 
secretary for research and development and advisor of Kennedy during his presidential campaign. Gardiner was influential in Kennedy's early space initiatives. It was suggested to Kennedy by Gardiner, that he favour a larger role for the military in the space effort. He did so by granting the Army greater input into their already planned space programs, and this helped soften their relationship to deal with the arms race..$^{20}$

The second major factor that led Kennedy to launch the Apollo program was the successful orbit of Soviet cosmonaut Yuri Gagarin, who became the first man in space in April 1961. Once again, the Soviet Union had accomplished another major milestone in the space race and bragged about their achievement over the U.S. internationally. ${ }^{21}$ Khrushchev stated Gagarin's space flight marked "A stage of the scientific/technical development of our country [Soviet Union] and reveals its mighty upward flights from backwardness to progress. In this flight are reflected the heroic accomplishments of the Soviet people, the working class, collective farm peasantry, working intelligentsia, and our wonderful scientists." ${ }^{22}$ Khrushchev spun this as a national effort and one that highlights the rapid progress of Soviet society. The state-controlled Soviet media was also sure to establish this success as part of its social structure and political system, being communism. Soviet propaganda even connected the Third World, as Gagarin was supposedly said to have waved to the people of Africa, who were struggling to break away from the chains of imperialism. ${ }^{23}$ This Soviet propaganda notably highlights that the space race was intrinsically connected to other theatres of the Cold War, especially foreign policy and the Third World.

\footnotetext{
${ }^{20}$ Logsdon, John F. Kennedy and the Race to the Moon, 18-22.

${ }^{21}$ Rita G. Koman, "Man on the Moon: The U.S. Space Program as a Cold War Maneuver," OAH Magazine of History, no. 2 (1994): 43-44.

22 Nikita Khrushchev to Pravda, 12 May 1961, in McDougall, The Heavens and the Earth, 244-245.

${ }^{23}$ McDougall, The Heavens and the Earth, 245-247.
} 
The international reaction to Gagarin's space flight was full of praise and wonder. The Soviets were quick to celebrate the achievement of Gagarin internally, before capitalizing on the propaganda of the successful flight. Many Soviet and eastern leaders painted the achievement as more than a science and technological one. East German Communist leader Walter Ulbricht famously said the flight "demonstrates to the whole of the world that socialism must triumph over the decaying system of yesterday." 24 Many other nations voiced their admiration of the Soviet achievement. In western Europe especially, where the U.S. had their closest allies, leaders were quick to congratulate the Soviets on their achievements. There were even reports in Britain of "anti-American barbs from men in the street." 25 These reactions highlight that the space race was a major aspect of the Cold War. The Soviets quickly turned their successes of Sputnik and Gagarin into a propaganda campaign to show the world their system was quickly surpassing that of the U.S. and the world was beginning to take notice.

The pressure following Gagarin's orbit around the Earth was just as great in the U.S. The American government was quiet on the Soviet space campaign and its capabilities, so this event, much like Sputnik, came as a shock to the U.S. public. Left with disappointment and embarrassment, the U.S. media was quick to criticize the Kennedy administration. The Washington Post wrote, "The fact of the Soviet space feat must be faced for what it is, and it is a psychological victory of the first magnitude for the Soviet Union... In these matters, what people believe is as important as the actual facts, and many persons will of course take this event as new evidence of Soviet superiority." ${ }^{26}$ An editorial writer for the New York Times, Harry Schwartz, attacked the president personally stating "The President, of course, had attempted to present

\footnotetext{
${ }^{24}$ Logsdon, John F. Kennedy and the Race to the Moon, 71-72.

${ }^{25}$ Logsdon, John F. Kennedy and the Race to the Moon, 72.

${ }^{26}$ Logsdon, John F. Kennedy and the Race to the Moon, 72.
} 
himself as an image of a young, active, and vigorous leader of a strong and advancing nation...Moreover, since he took office the President's image has been beset by the difficulties he has had with Congress, by his failure to spell out promised 'sacrifices' to be required of the American people and by the continued recession. ${ }^{.27}$ Kennedy had attempted to present himself as an active Cold War warrior and leader with a fresh face and new ideas. However, this image came under scrutiny by the media, who were implying that Kennedy was a weak leader and illequipped to deal with the pressures of the Cold War. The media also argued that voters were no longer falling for Kennedy's message of the U.S. being superior to that of the Soviet Union, especially in terms of science and technology. Kennedy was said to have been an avid newspaper reader and so easily would have been aware of what media and public pressure he was under.

However, it was the pressure and rhetoric spewed by the House of Representatives that would have the greatest effect on Kennedy's eventual desire to land an American on the moon. The Republicans in Congress were some of the most vocal in the aftermath of Gagarin's successful space orbit. The focus of many of these hearings was not on budgetary concerns for NASA, but rather to speed up the space programs. A planned hearing was scheduled for April 12, 1961 to revise the 1958 Space Act and make the Vice President the chairman of the Space Council. Once the representatives met the following day, Gagarin was the only topic on anyone's mind. ${ }^{28}$ The Democratic controlled house, especially the GOP, wanted greater funding for programs relating to human space flight and called for Kennedy to support these proposals. Kennedy had responded to congressional concerns about space earlier in the year, but these were overshadowed by Gagarin's space flight. Kennedy's administration was wary of these calls for

\footnotetext{
${ }^{27}$ Harry Schwartz, "Moscow: Flight is Taken as Another Sign that Communism is the Conquering Wave," The New York Times (16 April 1961): E3.

${ }^{28}$ Logsdon, John F. Kennedy and the Race to the Moon, 74.
} 
increased funding however. Republican James Fulton wanted no more secrets and demanded action, stating, "we in the United States should publicly say that we are in a competitive space race with Russia and accept the challenge. ${ }^{, 29}$

Kennedy and many of his closest advisors had been meeting for weeks to discuss the space race and capacity of the U.S. program. Another private meeting was held on April 14, 1961 between Kennedy and many of his closest advisors including officials from NASA, to address their response to the Soviet space programs. There was serious discussion given to planning something major and a serious consideration of the state of NASA's space capabilities. Kennedy was a very good listener, and his speechwriter Ted Sorensen asked about a human mission to the moon. The two leading NASA administrators, James E. Webb and Hugh Dryden, claimed such a goal would be a massive undertaking, but with adequate time and proper funding, the Americans could be the first to achieve this ambition..$^{30}$ The concerns over funding were shared by other advisors, most notably the chairman of the Science Advisory Committee, Jerome Wiesner, who wanted more time to conduct a more thorough assessment of NASA. Hugh Sidey was a journalist for Time magazine, but was trusted greatly by Kennedy. Sidey claims that Kennedy was giving greater consideration to the idea, but his primary concern was funding. Space was never at the top of Kennedy's priority up until the Soviet-manned spaceflight. Kennedy realized that his presidency needed something major and especially in terms of the space race. This meeting marked a major turning point in Kennedy's space approach, as Kennedy felt it was necessary to clearly define U.S. space aims and commit to their proposed

\footnotetext{
${ }^{29}$ Logsdon, John F. Kennedy and the Race to the Moon, 73-74.

${ }^{30}$ Logsdon, John F. Kennedy and the Race the Moon, 75.
} 
goals. Kennedy told Sidey following the meeting that the American response to the Gagarin flight would be "strong and dramatic...we're going to the moon".31

Meanwhile, another factor that affected Kennedy's decision to launch the Apollo program was the Bay of Pigs invasion in April 1961. Cuban leader Fidel Castro rose to power in January 1959, after a six-year rebellion against dictator Fulgencio Batista. Castro led a successful revolution, in which his reforms came as a response to the overwhelming presence of the United States in the nation's affairs. This revolution took on the shape of a communist one. By 1960, the U.S. was growing increasingly hostile, and thus Cuba turned to the Soviet Union for assistance. This response was received in February 1960, when Castro hosted a Soviet trade fair and both sides agreed to a commercial agreement. ${ }^{32}$ Eisenhower felt that Castro posed a threat to U.S. national security and recommended that Castro be removed as leader of Cuba. A propaganda campaign ensued, and efforts were made to strangle the Cuban economy. Kennedy, as a Senator in late 1959 and 1960, supported Eisenhower's belief that Cuba posed a threat to U.S. national security. Plans to invade the Bay of Pigs inlet of Cuba had been proposed and planned long before Kennedy took office during the Eisenhower administration. Kennedy was advised to authorize the invasion by CIA Director Allen Dulles. The Soviets and their ideas of communism had entered the American sphere of influence. This would be the closest the U.S. had to fight the Cold War militarily to their native soil. If Kennedy were to cancel, there would be political and public repercussions, as Castro was strongly disliked by the U.S. government and public. He would have been criticized for undermining the plans of one of America's most respected and trusted military leaders in Eisenhower. Kennedy would have been said to have feared Castro and

\footnotetext{
${ }^{31}$ Logsdon, John F. Kennedy and the Race to the Moon, 75-78.

${ }^{32}$ Stephen G. Rabe, John F. Kennedy: World Leader (Lincoln: Potomac Books, Inc., 2010), 51-54.
} 
be unfit as a Cold War leader. ${ }^{33}$ There were some Congressional leaders who advised Kennedy not to go through with the invasion during council meetings, as it raised "philosophical, diplomatic, and practical objections to the unprovoked invasion of a sovereign country." ${ }^{34}$ In the end Kennedy decided to authorize the Bay of Pigs invasion in large part due to the political implications if he did not and his own belief that the Castro regime needed to be taken down for U.S. security needs. This was a very big step for Kennedy, as it was the first major military action as president.

The invasion took place only five days following Gagarin's orbit of Earth from April 1720, 1961, and the eventual disaster would contribute to Kennedy's response of launching the Apollo program. ${ }^{35}$ Castro's forces were able to combat the 1400-men invasion force, with the revolutionary leader assuming military command. Castro was seen as an international hero to many, garnering support both domestically and from other Third World nations. The opposite was true in the U.S., as this was seen as a momentous disaster for U.S. foreign policy, and the Kennedy administration received the full brunt of the criticism. ${ }^{36}$ The White House leaked information about the Eisenhower administration's and other leaders' involvement in the invasion to minimize the blame on JFK. However, Kennedy later shared the blame publicly. He also criticized the press for printing too many stories about the Cuban situation, with the U.S. media allowing Castro to gain too much information. The mainstream U.S. press was even more outraged and added to Kennedy's discontent. The managing editor of the New York Times, Turner Catledge, questioned Kennedy's logic, stating "On the one hand, he condemned us for

\footnotetext{
33 Rabe, 54-56.

${ }^{34}$ Rabe, 56-57.

35 Andreas Reichstein, "John F. Kennedy and the Apollo Program: A Study in Political Decision-Making," Amerikastudien 39, no. 2 (1994): 214-215.

36 James N. Giglio and Stephen G. Rabe, Debating the Kennedy Presidency (Lanham: Rowman \& Littlefield Publishers, Inc., 2003), 32-35.
} 
printing too much and in the next breath he condemned us for printing too little. He wanted it both ways." 37

Within a week, Kennedy had seen two major failures in the realm of the Cold War. Gagarin's spaceflight had confirmed even more that the U.S. was severely lagging behind the Soviets in the space race, despite efforts to increase funding and take more time to ensure U.S. programs would be successful. The Bay of Pigs disaster also proved an embarrassment to his administration and raised doubts about Kennedy's foreign policy agenda, which he took great pride in as a Senator years earlier. Foreign policy and events in the Third World were key in fighting the Cold War, so Kennedy needed to rethink his foreign policy goals and reiterate the positives of American democracy. Kennedy's image as a young and ambitious leader was severely questioned. Kennedy needed something major to turn the perception of his administration around and something to define his presidency. In the months that followed April 1961, Kennedy would change the nature of the space race and his presidency at large.

Before Kennedy announced the development of the Apollo program, he was hoping for the success of Project Mercury. This was the first scheduled American human launch into space and was to take place on May 2, 1961. The event would be aired on live television, and the Kennedy administration was extremely worried about yet another failure. ${ }^{38}$ The launch was postponed until May 5 due to poor weather, but the man aboard the flight, Alan Shepard, was famously said to have said everything went "A-OK." Project Mercury was a major success for the Americans, but more specifically for Kennedy's Cold War fight. Shepard became a national hero, and the national response surprised Kennedy. 45 million Americans watched on national

\footnotetext{
${ }^{37}$ Reeves, 271-275.

${ }^{38}$ Logsdon, John F. Kennedy and the Race to the Moon, 79.
} 
television, and 250,000 came to honour Shepard at a ticker tape parade in New York City. ${ }^{39}$ The flight garnered a great deal of international praise, too. Despite the Soviet Union being the first to launch a man into space, the praise for the U.S. was in large part due to their openness of the Shepard flight. This helped the American image abroad, as Alan Shepard looked like a winner. A May 1961 report published by the U.S. Information Agency claimed that the Soviet Union was criticized for their secrecy and propaganda campaign surrounding the spaceflight by the international community. The report also claimed that Alan Shepard was also more well liked than Gagarin due to his humility, and Gagarin was said to have too much of a politically controlled behaviour by his superiors. ${ }^{40}$ The success of Project Mercury propelled new public enthusiasm for what was next. Kennedy was now sure to listen to the advice of many close advisors and Republican rivals about speeding up human spaceflight programs with the goal of catching up to the Soviet program and eventually surpassing it. ${ }^{41}$

On May 9, 1961, Vice President Lyndon B. Johnson finalized his report to Kennedy, which oversaw a thorough review of NASA and the capability of the American space program. The report outlined what NASA should be doing and how much funding was needed. Kennedy met with his advisers on May 10 to discuss the contents of the report and quickly concluded that he was in full support of the lunar landing goal. Kennedy was also advised to give updates on other issues at his "Urgent National Needs" address to Congress, as they were seen as important matters both to the world and Cold War at large. ${ }^{42}$ Kennedy saw the Apollo program as part of a larger foreign policy agenda to help present a positive image of the nation abroad and spread the

\footnotetext{
${ }^{39}$ Gerard J. DeGroot, Dark Side of the Moon: The Magnificent Madness of the American Lunar Quest (New York: New York University Press, 2006), 140-141.

${ }^{40}$ Logsdon, John F. Kennedy and the Race to the Moon, 96-98.

${ }^{41}$ John M. Logsdon, “John F. Kennedy's Space Legacy and Its Lessons for Today,” Issues in Science and Technology, no. 3 (2011): 29.

${ }^{42}$ Logsdon, John F. Kennedy and the Race to the Moon, 106-108.
} 
idea of American freedom and democracy. Kennedy would change the course of the American space program and the space race when he addressed the House on May 25, 1961.

Kennedy would address Congress in person, but his speech would also be televised for a national audience. The overall tone and theme of the speech was the need for American citizens to make sacrifices if the U.S. was going to combat the urgent national needs and continue to succeed as the global power they were. Kennedy emphasized that all of the programs would involve substantial costs and sacrifices, but these were necessary for the success of the nation. Kennedy then proceeded to discuss his most ambitious proposal last and in the most detail. Building on the arguments of the battle between freedom versus tyranny in the world, Kennedy reminded his audience of the impact of Sputnik on the minds of men everywhere. He then stated he had his Vice President, Lyndon B. Johnson, review the space program to see where America's capabilities laid. Advocating the U.S. possessed the resources, talent, as well as freedom to choose activities in space, Kennedy asked Congress to help fund his most ambitious national goal:

First, I believe that this nation should commit itself to achieving the goal, before this decade is out, of landing a man on the moon and returning him safely to Earth. No single space project in this period will be more impressive to mankind, or more important for the long-range exploration of space; and none will be so difficult or expensive to accomplish...But in a very real sense, it will not be one man going to the moon - if we make this judgement affirmatively, it will be the entire nation.

It is a most important decision that we make as a nation. But all of you have lived through the last four years and have seen the significance of space and the adventures in space, and no one can predict with certainty what the ultimate meaning will be of mastery of space. ${ }^{43}$

\footnotetext{
${ }^{43}$ John F. Kennedy, "Special Message to Congress on Urgent National Needs," Address before a Joint Session of Congress, Washington D.C. (25 May 1961), Para. 58-64.
} 
Kennedy had been very quiet on the space front and criticized Eisenhower's response to Sputnik very critically as a Senator. Now there was "a firm conclusion about the importance of space achievement." ${ }^{\text {44 }}$ Kennedy built on the propelled public enthusiasm from Alan Shepard's personality and his successful spaceflight during Project Mercury to announce the lunar initiative. There would be Congressional opposition and some critics out there, but excitement was emerging. ${ }^{45}$ Kennedy would soon have a major tool to fight back in the Cold War.

Overall, though, Kennedy did not have to worry about Congressional and Senate support for his accelerated space program and national goal of landing a man on the moon, symbolizing Cold War unity after a turbulent few months for the nation. Vice President Johnson had met with Congressional leaders beforehand about the matter and quelled the Republican opposition to the funding of the eventual Apollo program. A major reason for this support was because of the fascination of space exploration and the idea that technology was synonymous with national progress. The house wanted greater funding for space projects ever since Sputnik, and the only way to ensure technological progress was by funding large-scale projects and having the personnel available to consult such ambitions. The House of Representatives had changed drastically in this regard ever since the fiscal prudence and belief in minimal government early in the Eisenhower presidency ${ }^{46}$ There was a strong bipartisan support for the lunar initiative then, exemplified by the authorization bill passed on July 20 by a vote of 354 to 59 , with only some Republicans and further left leaning Democrats opposing the bill. Another bill pertaining to NASA funds passed on August 7, which increased funding by $\$ 1.7$ billion. This increase of $89 \%$ compared to the previous fiscal year helped kickstart the Apollo program into action. ${ }^{47}$ The

\footnotetext{
${ }^{44}$ Logsdon, John F. Kennedy and the Race to the Moon, 118.

${ }^{45}$ Logsdon, "John F. Kennedy's Space Legacy and Its Lessons for Today," 29-30.

${ }^{46}$ DeGroot, 142-143.

${ }^{47}$ Logsdon, John F. Kennedy and the Race to the Moon, 116.
} 
political repercussions of Kennedy's decision to launch the Apollo program were minimal.

Public morale was strong, which built on the excitement of Alan Shepard becoming a national hero. Most importantly, Congress overwhelmingly supported Kennedy's program and funding for it, in large part due to the groundwork commenced by many of his closest advisors.

Kennedy embarked on a propaganda campaign to build on the morale of the Apollo program and advocated the idea that America was winning the Cold War again, and Americans were willing to fight as a nation. One of the main ways Kennedy embarked on this campaign was through his speeches. A location for the manned spacecraft centre was needed, and Houston Texas became the chosen site. This was mainly because LBJ had been delegated a major influence over the Apollo program and was a native of Texas. The land was also donated by Humble Oil and Rice University. Kennedy's speech was subsequently given at Rice University on September 12, 1962 and is one of the most notable examples of this propaganda campaign. ${ }^{48}$ Kennedy begins by praising America's scientific and technological capabilities, before examining progress in history from ancient times to modern day. He then proceeds to ask, why land an American on the moon? Kennedy answers this question with the famous line arguing:

We choose to go to the moon. We choose to go to the moon in this decade and do other things, not only because they are easy, but because they are hard, because that goal will serve to organize and measure the best of our energies and skills, because that challenge is one that we are willing to accept, one we are unwilling to postpone, and one we intend to win, and the others too. ${ }^{49}$

Kennedy characterized the moon as a "new frontier," a concept very apparent in American history since the days of colonization and westward expansion. He characterized space as being

\footnotetext{
48 John W. Jordan, 2003, “Kennedy’s Romantic Moon and Its Rhetorical Legacy for Space Exploration,” Rhetoric and Public Affairs 6, no. 2 (2003): 209-210.

49 John F. Kennedy, "We Choose to go to the Moon," Address at Rice University on the Nation's Space Effort, Houston, Texas, September 12, 1962, Retrieved from http://www.copperas.com/jfk/rice.htm, Para. 16.
} 
full of unexplored possibilities, with only the U.S. possessing the freedoms to be able to explore the new frontier. There is a "beat the Soviets" undertone depicted in this speech, bringing many elements of the Cold War into this propaganda campaign. ${ }^{50}$ Kennedy implies that American democracy is a superior system and that the U.S. should fight for their political system militarily, ideologically, psychologically, and culturally. Kennedy also characterizes this moment as one of urgency and invited his audience to live up to the history by helping America go to the moon. ${ }^{51}$ This last point had been used a great deal by Kennedy in other speeches, but exemplifies that the Apollo program was more than just a political ambition; it had deep cultural ties to the U.S. populace. This was also critical to the Cold War, as there needed to be a cultural belief in American values and ideals and willingness for Americans to embrace and fight for American freedom and democracy.

Another of Kennedy's propaganda tactics in his decision to launch the Apollo program was to inspire current Americans, but especially the next generation, to dream of one day going to the moon themselves. Reader's Digest, in 1963, published a book entitled Treasury for Young Readers. The book featured many inspirational stories and activities for children. Within the book, one section focused on astronaut John Glenn and explored a day for him in space. This piece was meant to inspire children by telling the story of one of America's first astronauts and national heroes. Glenn gets to see the world from above and many beautiful sites one could only dream of. He encounters trouble, but his years of training prepared him for the issues at hand, and he was successful in his return to Earth. The section concludes with a brief biography of Glenn's life:

John Glenn was raised in the little Ohio town of New Concord... He always wanted to fly. And, as soon as he could, he joined the Marine Corps and won his

\footnotetext{
${ }^{50}$ Jordan, 210-211.

${ }^{51}$ Jordan, 220-221.
} 
gold wings... He flew many a dangerous mission in World War II and the Korean War; later became a test pilot for high-speed high-altitude airplanes. No one who knew his bravery and determination was surprised when, in 1959, he was chosen as one of America's first astronauts. ${ }^{52}$

Within this young reader's book, John Glenn is painted as an inspirational hero, whose goals were achieved through hard work. He is from a small American town and had a massive dream. This infers that any American boy could achieve these dreams and ambitions through hard work and dedication. There is also a military focus, highlighting that Glenn is willing to fight for his nation, democracy, and freedom. This is what America would need from its citizens, if they were to fight and win the Cold War.

NASA also took on the initiative to market the moon quite considerably. One of the major steps in this initiative was the publishing of exclusive articles in Life magazine. One of the most lucrative deals was agreed to on August 5, 1959, prior to Kennedy's presidency when the original Mercury 7 astronauts signed an exclusive contract with Life allowing the publication of exclusive access to their personal stories. One of these stories was again that of John Glenn's in 1962. Other stories featured the wives and children of the astronauts, helping paint the image of them being regular American citizens, in addition to being national heroes. ${ }^{53} \mathrm{NASA}$ also distributed a variety of films, radio broadcasts, and other methods of bringing the stories and wonders of space to the American public. Kennedy had inspired the U.S. population in political and cultural realms of the Cold War, and now NASA and other media outlets such as Reader's Digest were contributing greatly.

\footnotetext{
52 Time Inc., “John Glenn and His Days in Space,” in Reader's Digest, Treasury for Young Readers (New York: The Reader's Digest Association, 1963), 38-43.

${ }^{53}$ David Meerman Scott and Richard Jurek, Marketing the Moon: The Selling of the Apollo Lunar Program (Cambridge: The MIT Press, 2014), 18-19.
} 
In conclusion, the rest of John F. Kennedy's presidency would come to be defined by other theatres of the Cold War such as the Cuban Missile Crisis in October 1962, and his legacy was ultimately cut short as he was tragically assassinated on November 22, 1963. These moments came to define much of the popular notion and legacy of John F. Kennedy. That is why the aim of this paper is important, as it focuses on Kennedy's early years as president of the United States and assesses his legacy based on these characteristics. Americans would rally and dream about the goal of landing an American on the moon for the entire decade, and they would eventually see their dreams come true on July 20, 1969, when American astronaut Neil Armstrong became the first man on the moon. This was spun as victory in the space race and a major moment for the U.S. in the Cold War. John F. Kennedy may have never been able to see this great American moment, but he certainly played a major factor in 1961, when he decided to launch the Apollo program and believed in the dream and reality of landing an American on the moon. 


\section{Bibliography}

Carton, Andrew M. “'I'm Not Mopping the Floors, I'm Putting a Man on the Moon': How NASA Leaders Enhanced the Meaningfulness of Work by Changing the Meaning of Work." Administrative Science Quarterly 63, no. 2 (2018): 323-369.

DeGroot, Gerard J. Dark Side of the Moon: The Magnificent Madness of the American Lunar Quest. New York: New York University Press, 2006.

Dick, Steven J. Historical Studies in the Societal Impact of Spaceflight. Washington: National Aeronautics and Space Administration, 2015.

Erickson, Andrew S. "Revisiting the U.S.-Soviet Space Race: Comparing Two Systems in Their Competition to Land a Man on the Moon.” Acta Astronautica 148 (July 2018): 376-384.

Geelhoed, E. Bruce. "Dwight D. Eisenhower, the Spy Plane, and the Summit: A Quarter-Century Retrospective." Presidential Studies Quarterly 17, no. 1 (March 1987): 95-106.

Giglio, James N. and Stephen G. Rabe. Debating the Kennedy Presidency. Lanham: Rowman \& Littlefield Publishers, Inc., 2003.

Hall, R. Cargill. "Denied Territory: Eisenhower's Policy of Peacetime Aerial Overflight." Air Power History 56, no. 4 (Winter 2009): 4-9.

Jordan, John W. "Kennedy's Romantic Moon and Its Rhetorical Legacy for Space Exploration." Rhetoric and Public Affairs 6, no. 2 (2003): 209-31.

Kennedy, John F. “The New Frontier.” Democratic National Convention Nomination Acceptance Address delivered at Memorial Coliseum, Los Angeles, 15 July 1960. Retrieved from https://www.americanrhetoric.com/speeches/jfk1960dnc.htm.

Kennedy, John F. "Special Message to the Congress on Urgent National Needs". Address before a Joint Session of Congress, Washington D.C., 25 May 1961. Retrieved from https://en.wikisource.org/wiki/Special_Message_to_the_Congress_on_Urgent_National_ Needs.

Kennedy, John F. "We Choose to go to the Moon." Address at Rice University on the Nation's Space Effort, Houston, Texas, 12 September 1962. Retrieved from http://www.copperas.com/jfk/rice.htm.

Kercher, Stephen E. Revel with a Cause. Chicago: University of Chicago Press, 2006.

Koman, Rita G. "Man on the Moon: The U.S. Space Program as a Cold War Maneuver." OAH Magazine of History, no. 2 (1994): 42-50. 
Lawrence, W.H. "Kennedy Asks 1.8 Billion This Year to Accelerate Space Exploration, Add Foreign Aid, Bolster Defense.” The New York Times (26 May 1961). Retrieved from https://search-proquest-

com.proxy.library.brocku.ca/hnpnewyorktimes/docview/115472814/fulltextPDF/BA9EB 51C44C54ABDPQ/1? accountid=9744.

Logsdon, John M. John F. Kennedy and the Race to the Moon. New York: Palgrave Macmillan, 2010.

Logsdon, John M. “John F. Kennedy's Space Legacy and Its Lessons for Today.” Issues in Science and Technology, no. 3 (2011): 29-34.

Logsdon, John M. The Decision to go to the Moon: Project Apollo and the National Interest. Chicago: The University of Chicago Press, 1970.

McDougall, Walter A. The Heavens and the Earth: A Political History of the Space Race. Baltimore: Johns Hopkins University Press, 1997.

McDougall, Walter A. 2010. “1961: Shooting the Moon: Practical Rather than Idealistic Reasons Pushed President Kennedy to Challenge America to Land a Man on the Moon within the Decade. (Modern Era 1946-2010) (John. F. Kennedy). American Heritage.

Rabe, Stephen G. John F. Kennedy: World Leader. Lincoln: Potomac Books, Inc., 2010.

Reeves, Thomas C. A Question of Character: A Life of John F. Kennedy. New York: Free Press, 1997.

Reichstein, Andreas. 1994. "John F. Kennedy and the Apollo Program: A Study in Political Decision-Making.” Amerikastudien 39, no. 2 (1994): 213-232.

Schwartz, Harry. "Moscow: Flight is Taken as Another Sign that Communism is the Conquering Wave." The New York Times (16 April 1961): E3. Retrieved from https://searchproquestcom.proxy.library.brocku.ca/hnpnewyorktimes/docview/115399016/fulltextPDF/8E297B 167FCC493BPQ/1? accountid=9744.

Scott, David Meerman and Richard Jurek. Marketing the Moon: The Selling of the Apollo Lunar Program. Cambridge: The MIT Press, 2014.

Time Inc. "John Glenn and His Day in Space." In Reader's Digest, Treasury for Young Readers, 38-43. New York: The Reader's Digest Association, 1963 